\title{
Oxidative Stress Type Influences the Properties of Antioxidants Containing Polyphenols in RINm5F Beta Cells
}

\author{
Nathalie Auberval, ${ }^{1}$ Stéphanie Dal, ${ }^{1}$ William Bietiger, ${ }^{1}$ Elodie Seyfritz, ${ }^{1}$ Jean Peluso, ${ }^{2}$ \\ Christian Muller, ${ }^{2}$ Minjie Zhao, ${ }^{3}$ Eric Marchioni, ${ }^{3}$ Michel Pinget,,${ }^{1,4,5}$ \\ Nathalie Jeandidier, ${ }^{1,4,5}$ Elisa Maillard, ${ }^{1}$ Valérie Schini-Kerth, ${ }^{5}$ and Séverine Sigrist ${ }^{1}$ \\ ${ }^{1}$ UMR DIATHEC, EA 7294, Centre Européen d'Etude du Diabète, Université de Strasbourg, Fédération de Médecine \\ Translationnelle de Strasbourg, boulevard René Leriche, 67200 Strasbourg, France \\ ${ }^{2}$ UMR 7200 Laboratoire d'Innovation Thérapeutique, Faculté de Pharmacie, Université de Strasbourg, 67400 Illkirch, France \\ ${ }^{3}$ Chimie Analytique des Molécules Bioactives (CAMBA), Institut Pluridisciplinaire Hubert Curien (UMR 7178 CNRS/UDS), \\ 74 route du Rhin, 67400 Illkirch, France \\ ${ }^{4}$ Departement d'Endocrinologie, Diabète, Maladies Métaboliques, Pôle NUDE, Hôpitaux Universitaires de Strasbourg (HUS), \\ 67000 Strasbourg, France \\ ${ }^{5}$ UMR 7175 CNRS, Pharmacologie et Physico-Chimie, Faculté de Pharmacie, Université de Strasbourg, 67400 Illkirch, France
}

Correspondence should be addressed to Séverine Sigrist; s.sigrist@ceed-diabete.org

Received 11 February 2015; Accepted 4 June 2015

Academic Editor: Akhilesh K. Tamrakar

Copyright (C) 2015 Nathalie Auberval et al. This is an open access article distributed under the Creative Commons Attribution License, which permits unrestricted use, distribution, and reproduction in any medium, provided the original work is properly cited.

\begin{abstract}
The in vitro methods currently used to screen bioactive compounds focus on the use of a single model of oxidative stress. However, this simplistic view may lead to conflicting results. The aim of this study was to evaluate the antioxidant properties of two natural extracts (a mix of red wine polyphenols (RWPs) and epigallocatechin gallate (EGCG)) with three models of oxidative stress induced with hydrogen peroxide $\left(\mathrm{H}_{2} \mathrm{O}_{2}\right)$, a mixture of hypoxanthine and xanthine oxidase (HX/XO), or streptozotocin (STZ) in RINm5F beta cells. We employed multiple approaches to validate their potential as therapeutic treatment options, including cell viability, reactive oxygen species production, and antioxidant enzymes expression. All three oxidative stresses induced a decrease in cell viability and an increase in apoptosis, whereas the level of ROS production was variable depending on the type of stress. The highest level of ROS was found for the HX/XO-induced stress, an increase that was reflected by higher expression antioxidant enzymes. Further, both antioxidant compounds presented beneficial effects during oxidative stress, but EGCG appeared to be a more efficient antioxidant. These data indicate that the efficiency of natural antioxidants is dependent on both the nature of the compound and the type of oxidative stress generated.
\end{abstract}

\section{Introduction}

Oxidative stress can be defined as an imbalance between proand antioxidants and is often associated with free radical [1] overproduction and/or defective physiological defence mechanisms resulting in the cell being overwhelmed with oxidizing radicals [2]. This phenomenon involves reactive oxygen species [3], such as superoxide anion $\left(\mathrm{O}_{2}{ }^{-}\right)$[4], hydroxyl radical $\left(\mathrm{OH}^{*}\right)[1]$, singlet oxygen $\left({ }^{1} \mathrm{O}_{2}\right)$, and hydrogen peroxide $\left(\mathrm{H}_{2} \mathrm{O}_{2}\right)$ [5]. High concentrations of ROS can cause lipid peroxidation, protein oxidation or denaturation, nuclear acid oxidation, and many other macromolecular changes that can lead to serious cellular damage [6]. Such ROS-related damage has been identified to occur in numerous diseases, including metabolic syndrome, diabetes, multiple types of cancer, Alzheimer's disease, and cardiovascular diseases.

Further, obesity, hyperglycemia, and hyperlipidemia have also been shown to promote oxidative stress through elevated ROS production [7], which is likely due to the higher occurrence of mitochondrial dysfunction and superoxide production that has been associated with fat accumulation [8]. Under normal conditions, enzymatic defence mechanisms [9], such 
as scavenging by superoxide dismutase [10] and glutathione peroxidase, are active in most types of cells to degrade ROS and prevent cellular damage. However, the antioxidant defence system functioning in insulin producing beta cells, which have been linked to both diabetes and obesity, is known to be very weak $[1,11,12]$, making these beta cells highly sensitive to oxidative stress, which can lead to cell death and disease [5]. Notably, the prevention of ROS-related beta cell destruction using antioxidant compounds has been identified to be an effective strategy to delay the onset of diabetes $[10,13,14]$.

In fact, several dietary plants that have pharmacological properties shown to prevent apoptosis induced by oxidative stress are under investigation as treatment options for diabetes $[9,15]$. Some of these plants appear to utilize antioxidant mechanisms related to their rich flavonoid (polyphenols family) content. The unique chemical structures and redox properties of these polyphenols [16] allow them to scavenge free radicals as well as chelate transition metals and inhibit prooxidant enzymes, such as inducible nitric oxide synthase (iNOS) in macrophages [17]. For example, tea catechins, especially epigallocatechin gallate (EGCG), appear to have antiobesity and antidiabetic properties [11, 18], and the beneficial effects of red wine polyphenols (RWPs) in diabetics have been widely documented [19]. RWPs are qualitatively and quantitatively rich in polyphenols, particularly anthocyanins, flavonol, and stilbene. In general, polyphenols are characterized by antioxidant activity and in vitro studies have shown that they act as radical peroxyl scavengers [20]. However, most of these in vitro studies were performed using a single model of stress, such as hypoxanthine/xanthine oxidase (HX/XO) [21] or $\mathrm{H}_{2} \mathrm{O}_{2}[22,23]$, whereby $\mathrm{HX} / \mathrm{XO}$ was a direct supplier in $\mathrm{O}_{2}{ }^{-}$, while $\mathrm{H}_{2} \mathrm{O}_{2}$ activated NADPH oxidase or NOS which produce $\mathrm{O}_{2}{ }^{-}$. In diabetes, in addition to $\mathrm{O}_{2}{ }^{-}$, generated by chronic hyperglycemia [4], other types of ROS are produced during insulin resistance and hyperinsulinism development [24]. Therefore, a single model of oxidative stress does not reflect the full complexity of this disease. In more relevant studies, oxidative stress was induced by multiple mechanisms using cytokines [25], alloxan [26], or streptozotocin [9, 27]. Notably, STZ is an NO donor and induces the formation of several kinds of ROS (e.g., $\mathrm{O}_{2}^{-\bullet}, \mathrm{H}_{2} \mathrm{O}_{2}, \mathrm{OH}^{\bullet}$, and peroxynitrite; Szkudelski, 2001) as well as DNA alkylation and tricarboxylic citric acid (TCA) cycle inhibition, all of which lead to cell damage and death. Thus, STZ can be used to induce multiple levels of oxidative stress in order to more appropriately mimic that which occurs during diabetes in vivo.

Obviously the oxidative stress observed during diabetes is complex, and the screening of antioxidant compounds cannot be reduced to the use of a single chemical stress. It is therefore important to validate the antioxidant properties of each antioxidant treatment compound, such as the RWPs, using both simple (single) and complex (multiple) oxidative mechanisms. The aim of this study was to create three in vitro models of oxidative stress (one with single radicals produced by $\mathrm{HX} / \mathrm{XO}$ and two with more complex oxidative reactions using $\mathrm{H}_{2} \mathrm{O}_{2}$ and STZ) in order to assess the antioxidant efficiencies of a RWP extract and a purified extract of EGCG.

\section{Materials and Methods}

2.1. Cell Line. Rat insulinoma clone m5F (RINm5F) [28] cells were purchased from the American Type Culture Collection (ATCC, Manassas, USA). Cells were cultivated in Roswell Park Memorial Institute (RPMI-1640) medium supplemented with $10 \%$ fetal bovine serum (FBS; Sigma, St. Louis, USA) and $1 \%$ antibiotic-antimycotic (ABAM; Gibco, Invitrogen, Grand Island, USA). Cells were grown in a humidified 5\% $\mathrm{CO}_{2}$ atmosphere at $37^{\circ} \mathrm{C}$ and trypsinized at $80 \%$ confluence using $0.05 \%$ trypsin EDTA (Sigma). Medium was refreshed every 48 hours.

2.2. Antioxidant Molecules. The RWP extract used in this study was generously given by Dr. M. Moutounet (National Institute of Agronomic Research, Montpellier, France). Red wine phenolic extract dry powder was obtained from French red wine (Corbières AOC) and analyzed by Dr. P.-L. Teissedre (Département d'Oenologie, Bordeaux, France). The extract was prepared as previously described [29]: briefly, phenolic compounds were adsorbed on a preparative column and, then, alcohol desorbed; the alcoholic eluent was gently evaporated; the concentrated residue was lyophilized and finely sprayed to obtain the phenolic extract dry powder. One liter of red wine produced $2.9 \mathrm{~g}$ of phenolic extract, which contained $471 \mathrm{mg} / \mathrm{g}$ of total phenolic compounds expressed as gallic acid. Phenolic levels in phenolic extract were measured by HPLC. The extract contained $8.6 \mathrm{mg} / \mathrm{g}$ catechin, $8.7 \mathrm{mg} / \mathrm{g}$ epicatechin, dimers (B1: $6.9 \mathrm{mg} / \mathrm{g}, \mathrm{B} 2: 8.0 \mathrm{mg} / \mathrm{g}$, B3: $20.7 \mathrm{mg} / \mathrm{g}$, and B4: $0.7 \mathrm{mg} / \mathrm{g}$ ), anthocyanins (malvidin3-glucoside: $11.7 \mathrm{mg} / \mathrm{g}$, peonidin-3-glucoside: $0.66 \mathrm{mg} / \mathrm{g}$, and cyanidin-3-glucoside: $0.06 \mathrm{mg} / \mathrm{g}$ ), and phenolic acids (gallic acid: $5.0 \mathrm{mg} / \mathrm{g}$, caffeic acid: $2.5 \mathrm{mg} / \mathrm{g}$, and caftaric acid: $12.5 \mathrm{mg} / \mathrm{g})$.

A stock solution of this RWP extract was prepared by diluting $10 \mathrm{mg} / \mathrm{mL}$ in a 1:1 mixture of distilled water and $100 \%$ ethanol. The EGCG extract was a pure form of green tea Teavigo (DSM Nutritional Product, Gland, Switzerland). To confirm its purity, Teavigo was analysed using chromatographic separation on a octadecylsilyl silica gel LC column (l: $0.125 \mathrm{~mm}$; d: 4; $0 \mathrm{~mm}$; Thermo Scientific, France) with spherical particles. Mobile phase consisted of water : formic acid $(0.1 \%$, phase $A)$ and methanol : formic acid $(0.1 \%$, phase B). A split system was used allowing the HPLC eluate to enter the MS detector at a flow rate of $0.2 \mathrm{~mL} / \mathrm{min}$. The injection volume was $20 \mu \mathrm{L}$. UV spectral data were acquired at $275 \mathrm{~nm}$ (the chromatogram was presented in Supplementary Material available online at http://dx.doi.org/10.1155/2015/859048). The extract was prepared at a $10 \mathrm{mg} / \mathrm{mL}$ stock solution concentration which was then diluted in $1 \times$ phosphate-buffered saline (PBS), pH 7.4 (Gibco, Invitrogen) as previously described [18]. Cells were cultured for 48 hours before all treatments. The antioxidant compounds (200 to $1000 \mathrm{pg} / \mathrm{mM}$ for the EGCG and 100 to $1000 \mu \mathrm{g} / \mathrm{mL}$ for the RWPs) were added to cells seeded in 96-well treated microplates (BD Falcon, Franklin Lakes, USA) at 30,000 cells/well and incubated for 1 hour. The toxicity of the EGCG and RWP extracts was then assessed as described below. 
2.3. Oxidative Stress Induction and Protective Effects of EGCG and RWPs. Oxidative stress was induced in the RINm5F cells with (1) $\mathrm{H}_{2} \mathrm{O}_{2}$ using a $33 \%$ daily prepared solution [30] that was diluted with culture medium to multiple concentrations $(1,10,25$, and $40 \mu \mathrm{mol} / \mathrm{L})$; (2) a mixture of various $\mathrm{HX}$ (mmol/ $\mathrm{L})$ to $\mathrm{XO}(\mathrm{mU} / \mathrm{mL})$ ratios $(0.05 / 2,0.2 / 8,0.25 / 10$, and $0.3 / 12)$ isolated from butter milk [22]; and (3) a $40 \mu \mathrm{mol} / \mathrm{L}$ solution of STZ prepared in $0.1 \mathrm{~mol} / \mathrm{L}$ citrate buffer solution, $\mathrm{pH} 4.2$ (27, 25 , and $40 \mu \mathrm{mol} / \mathrm{L}$, prepared in $\mathrm{pH} 4.2$ citrate buffer solution $(0.1 \mathrm{~mol} / \mathrm{L}))$ [27]. All products were purchased from Sigma.

To evaluate the toxicity of the EGCG and RWP antioxidants alone, various concentrations (EGCG at 200, 500, and $1000 \mu \mathrm{g} / \mathrm{mL}$; RWPs at $10,50,100,150$, and $200 \mu \mathrm{g} / \mathrm{mL}$ ) were added to stressed and unstressed cells and incubated for 1 hour.

2.4. MTS Assay. Cell viability was assessed by measuring the mitochondrial activity with the CellTiter 96 AQueous One Solution Cell Proliferation Assay from Promega Corporation (Madison, USA). After treatment, $100 \mu \mathrm{L}$ of culture medium containing $20 \mu \mathrm{L}$ of 3-(4,5-dimethylthiazol-2-yl)-5-(3-carbo xymethoxyphenyl)-2-(4-sulfophenyl)-2H-tetrazolium (MTS) was added. Cells were incubated for 2 hours at $37^{\circ} \mathrm{C}$, in $5 \% \mathrm{CO}_{2}$, and the absorbance was measured at $490 \mathrm{~nm}$ with a Metertech 960 microplate reader (Metertech Inc., Taipei, Taiwan). The quantity of the formazan product was directly proportional to the mitochondrial activity related to number of living cells. Results are expressed as the percentage of cell viability compared to the appropriate negative controls.

\subsection{Flow Cytometry}

2.5.1. Caspase 8. Oxidative stress often affects the cells very quickly, making it difficult to identify the primary apoptotic effects of the ROS. Therefore, the expression and/or activity of initiator caspases, such as caspase 8 [31], are often used to study apoptosis in this context as they reflect the initial effects of oxidative stress. Here, the activity of caspase 8 was determined by flow cytometry using fluorescent inhibitor of activated caspase 8 (caspase 8 FAM; Millipore, Guava Technologies, Hayward, CA). Briefly, cells were seeded in 96well treated microplates (BD Falcon, Franklin Lakes, USA) at 30,000 cells/well. After treatment, fresh medium supplemented with $10 \mu \mathrm{L}$ of caspase inhibitor was added. After mixing, plates were incubated for 1 hour at $37^{\circ} \mathrm{C}$ and centrifuged for 5 minutes at $300 \times \mathrm{g}$. Cells were then resuspended and $200 \mu \mathrm{L}$ of 7 -aminoactinomycin D ( $\left.7^{\prime} \mathrm{AAD}\right)$ was added and incubated for 10 minutes at room temperature in the dark before analysis. A Guava Easycyte microcapillary flow cytometer (Millipore) was used with laser excitation at $488 \mathrm{~nm}$ in order to detect caspase 8 FAM emission at $517 \mathrm{~nm}$ with carboxyfluorescein [6] according to the manufacturer's instructions. For each assay, 200 cellular events were collected. Results were analysed with CytoSoft software (Guava Technologies Inc., Hayward, CA, USA) and are expressed as the percentage of stained cells.

2.5.2. ROS Production. Cells were seeded in 24-well treated microplates (BD Falcon, Franklin Lakes, USA) at 500,000 cells/well. After treatment, $500 \mu \mathrm{L}$ of fresh medium supplemented with $2^{\prime}, 7^{\prime}$-dichlorofluorescein diacetate (DCFH-DA; Sigma) at final concentration of $5 \mu \mathrm{M}$ [32] was added. DCFH$\mathrm{DA}$ is deacetylated by a membrane esterase, forming $\mathrm{DCFH}$, which is then transformed by intracellular $\mathrm{H}_{2} \mathrm{O}_{2}$ to a fluorescent molecule [28]. Cells were incubated for 1 hour and then trypsinized. After centrifugation during 10 minutes $(500 \times \mathrm{g})$, pellets were dissolved with $500 \mu \mathrm{L}$ PBS and $200 \mu \mathrm{L}$ of the cell solution was transferred to 96 -well treated microplates. The suspended cells were then treated with $10 \mu \mathrm{L}$ of propidium iodide [11] for 15 minutes and assayed for fluorescence by flow cytometry at $530 \mathrm{~nm}$. Assays were analyzed with CytoSoft software and the results are expressed as a percentage of ROS production (DCF-labelled cells) compared to the appropriate negative controls.

2.6. Antioxidant Enzyme Expression: Catalase (CAT) and Manganese Superoxide Dismutase (MnSOD). Protein extracts were prepared from the treated cells using lysis buffer containing $20 \mathrm{mM}$ Tris ultrapure $\mathrm{pH} 8$ (Euromedex, Mundolsheim, France), $137 \mathrm{mM} \mathrm{NaCl}$ (Sigma), 1\% Igepal CA-630 (Sigma), $31 \mathrm{mM}$ phenyl methyl sulfonide fluoride (Eurobio, Les Ulis, France), and 10\% glycerol (Sigma) with protease inhibitor Complete Mini 1X (Roche, Indianapolis, USA). The protein content of each was measured using the methods of Bradford [33].

A $50 \mu \mathrm{g}$ aliquot of the total protein was then separated on 4-12\% Bis-Tris Criterion XT Precast Gels (Bio-Rad), transferred to $0.45 \mu \mathrm{m}$ nitrocellulose membranes (Bio-Rad), and detected with the following primary antibodies: anti-catalase produced in mouse (Sigma) or anti-MnSOD produced in rabbit (Sigma), each diluted to $1 / 1000^{\mathrm{e}}$, as well as a $1 / 5000^{\mathrm{e}}$ dilution of anti- $\beta$-actin monoclonal antibody produced in mouse. All antibodies were diluted in blocking buffer from the WesternBreeze Chemiluminescent Kit (Invitrogen, Grand Island, USA) overnight at $4^{\circ} \mathrm{C}$. Secondary antibody solution (anti-mouse (1/2000) or anti-rabbit (1/4000) coupled to alkaline phosphatase) was incubated with the membranes for 30 minutes with continuous rotation as described in the kit. Membranes were then exposed with a Bio-Rad ChemiDoc XRS System for 600 seconds, and the captured images were analysed using Quantity One software. Expression of CAT and MnSOD proteins was normalized to the quantity of $\beta$-actin and expressed as a percentage compared to the appropriate negative controls.

2.7. Statistical Analysis. Samples were assayed at least three times for each test and the results are given as the mean \pm standard error (SEM). Data were analysed with one-way analysis of variance [34] when designated using the Statistica program (Statsoft $\odot$, Créteil, France). Treatment differences were subjected to Fischer's test with a 95\% significance $(P<$ $0.05)$ threshold.

\section{Results}

3.1. Cellular Effects of Various Oxidative Stressors. We first screened the cell viability following treatment with multiple 


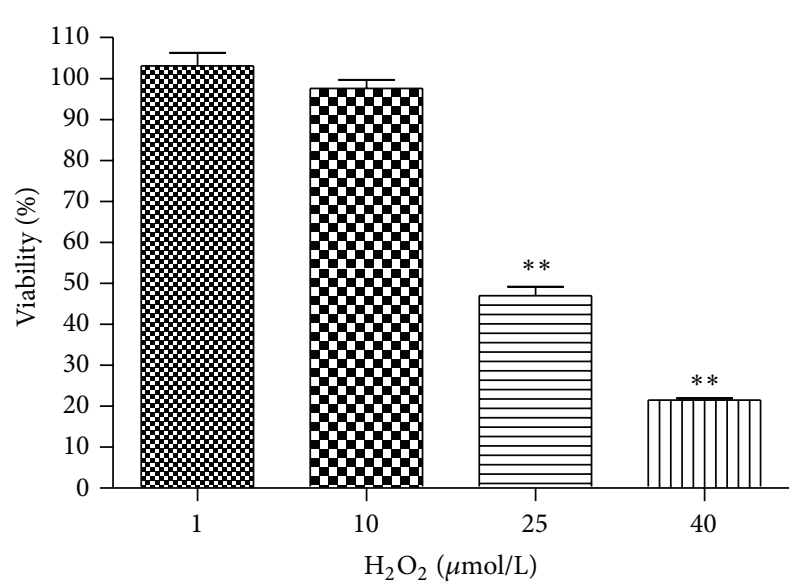

(a)

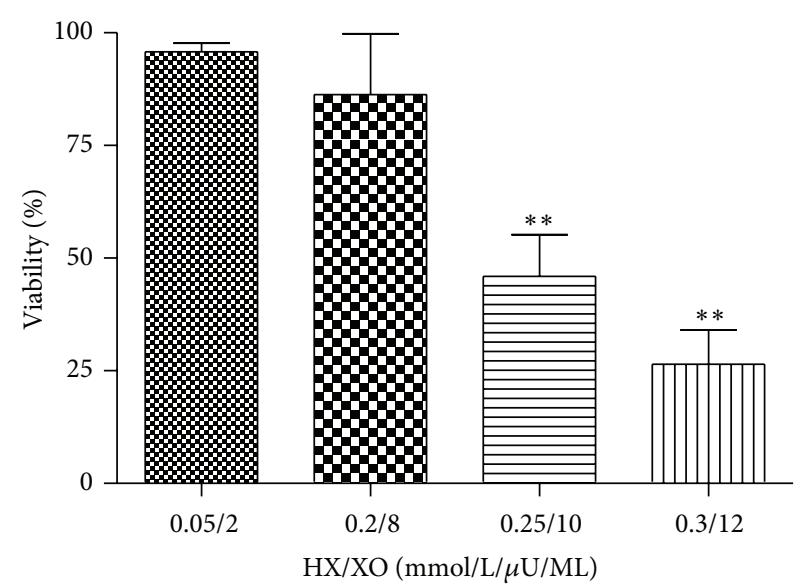

(b)

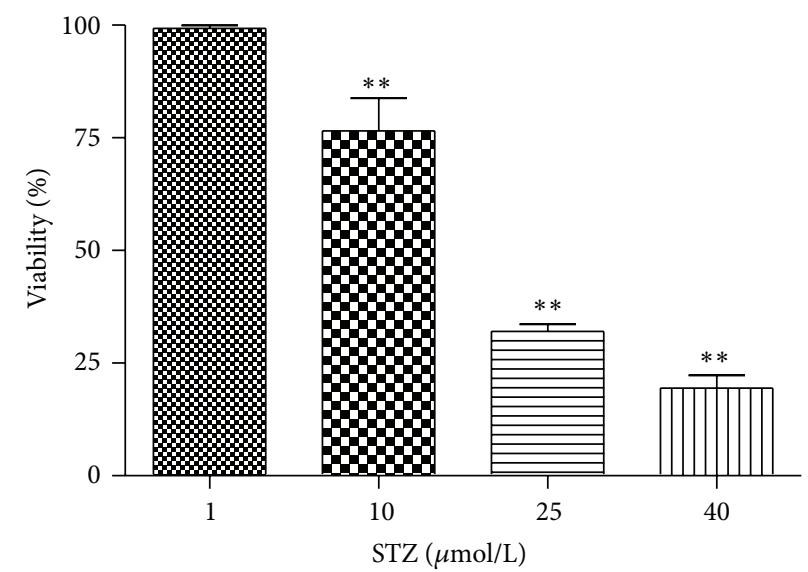

(c)

Figure 1: Effects of $\mathrm{H}_{2} \mathrm{O}_{2}$ (a), HX/XO (b), and STZ (c) on RINm5F cell viability. Values are given as the mean \pm SEM for three different experiments. $n=6 ;{ }^{*} P<0.05$ and ${ }^{* *} P<0.01$ compared to the control cells.

concentrations of each oxidative molecule to determine the concentration of each that induced RINm5F cell death in at least $50 \%$ of the culture (Figure 1). $\mathrm{H}_{2} \mathrm{O}_{2}$ appears to induce a significant decrease in cell viability at concentrations above $25 \mu \mathrm{mol} / \mathrm{mL}(P<0.01)$, with the lowest number of viable cells reaching $21.4 \pm 0.5 \%$ at the $40 \mu \mathrm{mol} / \mathrm{mL}$ concentration (Figure 1(a)). Further, a ratio of $0.25 \mathrm{mmol} / \mathrm{L}$ of $\mathrm{HX}$ and $10 \mathrm{mU} / \mathrm{mL}$ of XO was sufficient to induce a significant loss of cell viability, resulting in only $45.9 \pm 9.2 \%$ of the cells being viable at this ratio $(P<0.01)$ (Figure $1(\mathrm{~b}))$. Finally, even though the $10 \mathrm{mmol} / \mathrm{L}$ concentration of STZ induced a significant decrease in cell viability, leaving only $76.5 \pm$ $0.7 \%$ of the cells $(P<0.01)$, a more marked reduction of cell viability similar to that of the other oxidants was observed at $25 \mathrm{mmol} / \mathrm{L}$, which resulted in only $32 \pm 1.6 \%$ of the cells remaining alive in the culture $(P<0.01)$ (Figure 1(c)). Concentrations that induced a loss greater than $50 \%\left(25 \mu \mathrm{mol} / \mathrm{L}\right.$ of $\mathrm{H}_{2} \mathrm{O}_{2}$, a ratio of $0.25 \mathrm{mmol} / \mathrm{L}$ of $\mathrm{HX}$ and $10 \mathrm{mU} / \mathrm{mL}$ of $\mathrm{XO}$, and $25 \mathrm{mmol} / \mathrm{L}$ of STZ) were the sole concentrations used in the subsequent analyses to study the antioxidant properties of the EGCG and RWP extracts.
3.2. Antioxidant Toxicity Assessment. The potential toxicity of each antioxidant extract on the unstressed RINm5F cells was evaluated by measuring the cell viability in the presence of different concentrations of EGCG and RWPs (Figure 2). RWPs appear to have no effect on cell viability until reaching a concentration of $500 \mu \mathrm{g} / \mathrm{mL}$, at which point the number of viable cells drops to $92.4 \pm 14.7 \%$ (not significant). A dosedependent decreasing trend in cell viability was also observed around this concentration; however, this decrease was not significant until the RWP concentration reached $1000 \mu \mathrm{g} / \mathrm{mL}$ $(P<0.05)$ (Figure $2(a))$. In contrast, EGCG was observed to induce a significant increase in cell viability at the $500 \mu \mathrm{g} / \mathrm{mL}$ $(152 \pm 26 \%, P<0.01)$ and $1000 \mu \mathrm{g} / \mathrm{mL}(233.5 \pm 13.0 \%$, $P<0.01$ ) concentrations (Figure 2(b)).

3.3. Effects of EGCG and RWPs during $\mathrm{H}_{2} \mathrm{O}_{2}$-Induced Oxidative Stress. RWPs were shown to reduce the loss of RINm5F cell viability induced by $\mathrm{H}_{2} \mathrm{O}_{2}$ oxidative stress (Figure 3(a)) in a dose-dependent manner starting at a concentration of $50 \mu \mathrm{g} / \mathrm{mL}(32.4 \pm 1.8 \%, P<0.01)$ and reaching a maximum level at $200 \mu \mathrm{g} / \mathrm{mL}(73.9 \pm 3.5 \%, P<0.01)$, the highest 


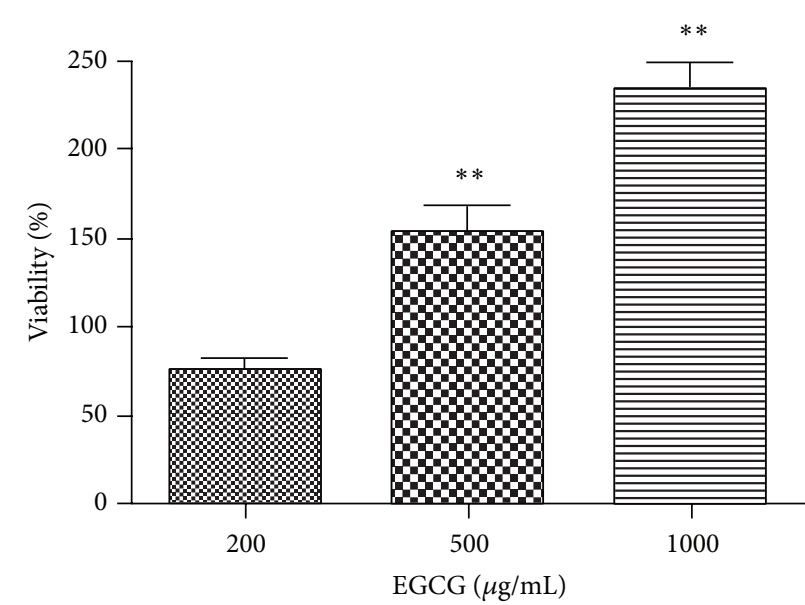

(a)

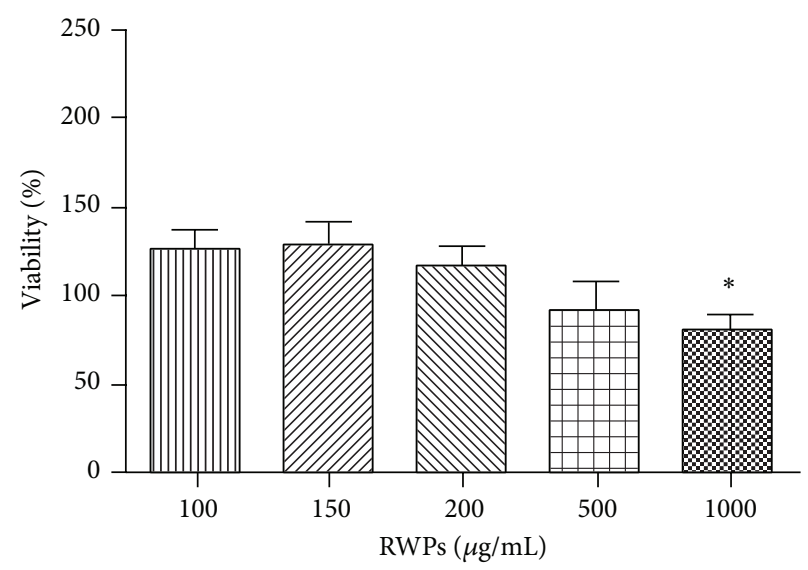

(b)

FIGURE 2: Effects of RWPs (a) and EGCG (b) on RINm5F cell viability. Values are given as the mean \pm SEM for three different experiments. $n=6 ;{ }^{*} P<0.05$ and ${ }^{* *} P<0.01$ compared to the control cells.

concentration used in this study. Further, $500 \mu \mathrm{g} / \mathrm{mL}$ of EGCG was sufficient to significantly improve cell viability after oxidative stress $(82.3 \pm 6.2 \%, P<0.01)$ (Figure 3(b)). This effect again appeared to be dose-dependent, with the cell viability being completely restored and enhanced at an EGCG concentration of $1000 \mu \mathrm{g} / \mathrm{mL}(110 \pm 8.9 \%, P<0.01)$.

The antioxidant properties of RWPs and EGCG were also confirmed by measuring apoptosis through the evaluation caspase 8 expression using $150 \mu \mathrm{g} / \mathrm{mL}$ of RWPS and $500 \mu \mathrm{g} / \mathrm{mL}$ of EGCG. Both antioxidants appear to reduce the significant increase in caspase 8 activation observed during $\mathrm{H}_{2} \mathrm{O}_{2}$-induced oxidative stress back to levels similar to the unstressed control cells $(P<0.01)$. Surprisingly, the significant increase in ROS production observed during $\mathrm{H}_{2} \mathrm{O}_{2}$ oxidative stress was not reduced by the RWP extract; it actually appeared to induce an increase in ROS production, going from $11.1 \pm 2.1 \%$ to $19.2 \pm 1.9 \%(P<0.01)$. On the other hand, EGCG extract significantly reduced ROS production during oxidative stress. In terms of antioxidant enzyme expression during $\mathrm{H}_{2} \mathrm{O}_{2}$-induced oxidative stress, MnSOD (Figure 3(e)) and CAT protein expression (Figure 3(f)) was comparable to that of the unstressed control cells. Further, MnSOD protein expression was significantly reduced by RWPs during oxidative stress $(P<0.05)$, while CAT protein expression was reduced using EGCG $(P<0.01)$.

3.4. Effects of EGCG and RWPs on HX/XO-Induced Oxidative Stress. The significant decrease RINm5F cell viability observed during $\mathrm{HX} / \mathrm{XO}$-induced oxidative stress was significantly increased when $200 \mu \mathrm{g} / \mathrm{mL}$ of RWP was added, but the percentage of viable cells did not exceed $40.2 \pm 1.9 \%(P<0.01)$ (Figure $4(\mathrm{a})$ ). The efficiency of EGCG to improve the viability of stress cells was similar to that observed for RWPs at the $200 \mu \mathrm{g} / \mathrm{mL}$ concentration ( $43.1 \pm 3.8 \%$ ), although this was not significant (Figure 4(b)). However, at higher concentrations EGCG was able to significantly increase cell viability from $16.5 \pm 2.1 \%$ in the stressed control cells to $88.5 \pm 7.4 \%$ at
$500 \mu \mathrm{g} / \mathrm{mL}(P<0.01)$ and over $100 \%$ at the $1000 \mu \mathrm{g} / \mathrm{mL}$ concentration.

Further, the $150 \mu \mathrm{g} / \mathrm{mL}$ and $500 \mu \mathrm{g} / \mathrm{mL}$ concentrations of RWPs and EGCG, respectively, were then used to study their antioxidant properties during $\mathrm{HX} / \mathrm{XO}$-induced oxidative stress. It appears that these concentrations of RWPs and EGCG significantly reduce caspase 8 cleavage during HX/XO-induced oxidative stress $(P<0.05$ and $P<0.01$, resp.; Figure 4(c)), bringing the caspase 8 activity back down to levels similar to the unstressed control cells. Moreover, both antioxidants significantly reduced the ROS production as well (Figure 4(d)). Notably, only EGCG was observed to increase the protein expression of MnSOD (Figure 4(e)) and CAT (Figure 4(f)) during HX/XO-induced oxidative stress.

3.5. Effects of EGCG and RWPs on STZ-Induced Oxidative Stress. The significant decrease in cell viability during STZinduced oxidative stress was slightly opposed by $200 \mu \mathrm{g} / \mathrm{mL}$ of RWPs, which significantly increased the number of viable cells to a mere $50.6 \pm 0.5 \%(P<0.01)$. Similarly, a $1000 \mu \mathrm{g} / \mathrm{mL}$ concentration of EGCG was needed to significantly increase the cell viability during STZ-induced oxidative stress (60 \pm $14 \%, P<0.05$ ) (Figure 5(b)). For further investigation of the antioxidant properties of the RWPs and EGCG extracts during this type of oxidative stress, we focused on the $200 \mu \mathrm{g} /$ $\mathrm{mL}$ and $1000 \mu \mathrm{g} / \mathrm{mL}$ concentrations of RWPs and EGCG, respectively.

Notably, caspase 8 activation was not observed to increase during STZ-induced oxidative stress; the addition of either of the antioxidants did not significantly change these levels compared to the unstressed or stressed control cells (Figure 5(c)). However, the production of ROS was significantly increased during STZ-induced stress and only EGCG treatment caused a significant reduction of this induced ROS production $(P<$ 0.05; Figure 5(d)). The unaltered MnSOD (Figure 5(e)) and CAT (Figure 5(f)) protein expression during STZ-induced oxidative stress was also only affected by the addition of EGCG. 


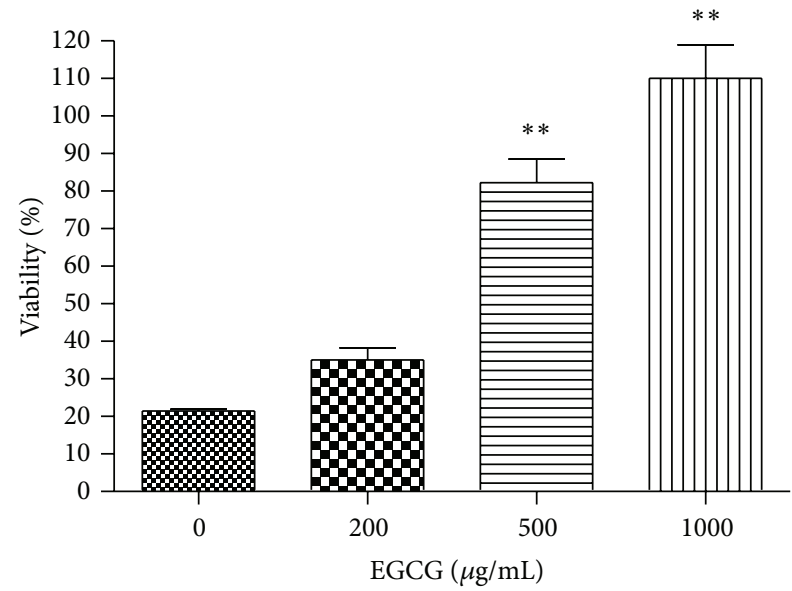

(a)

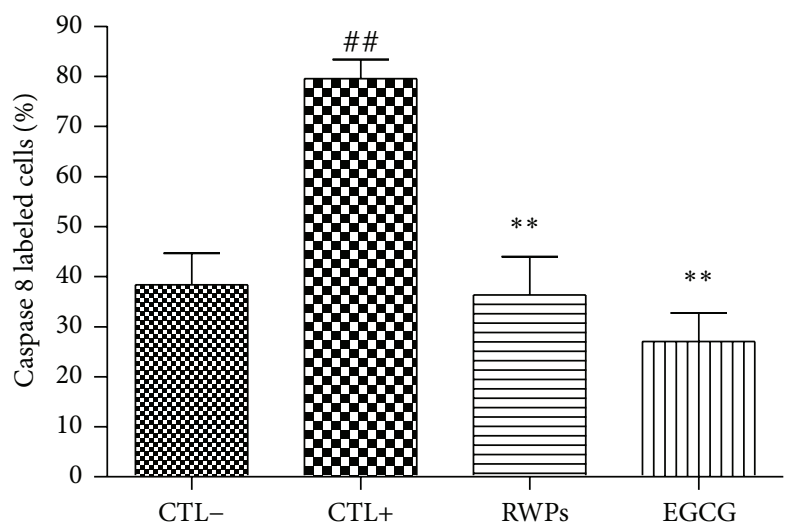

(c)

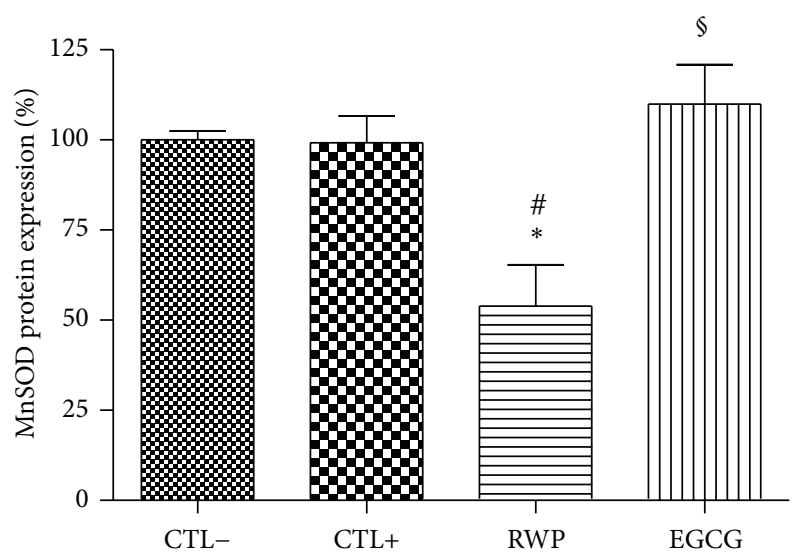

(e)

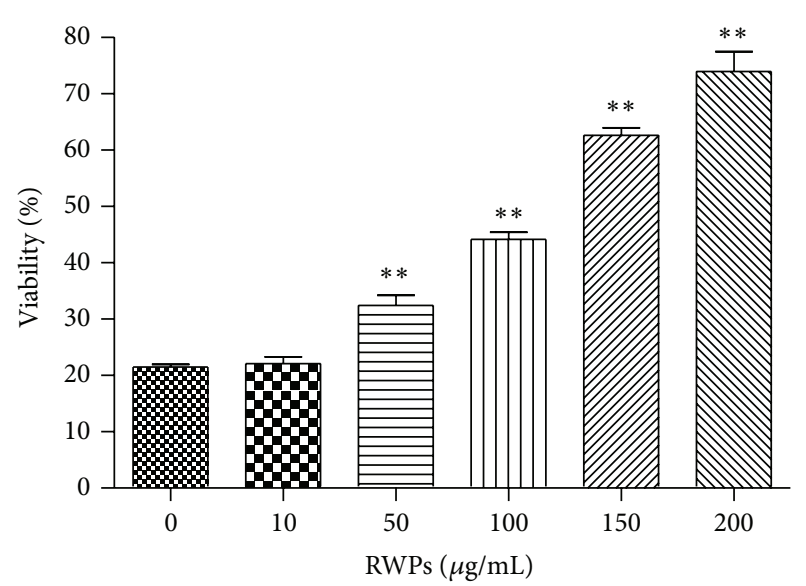

(b)

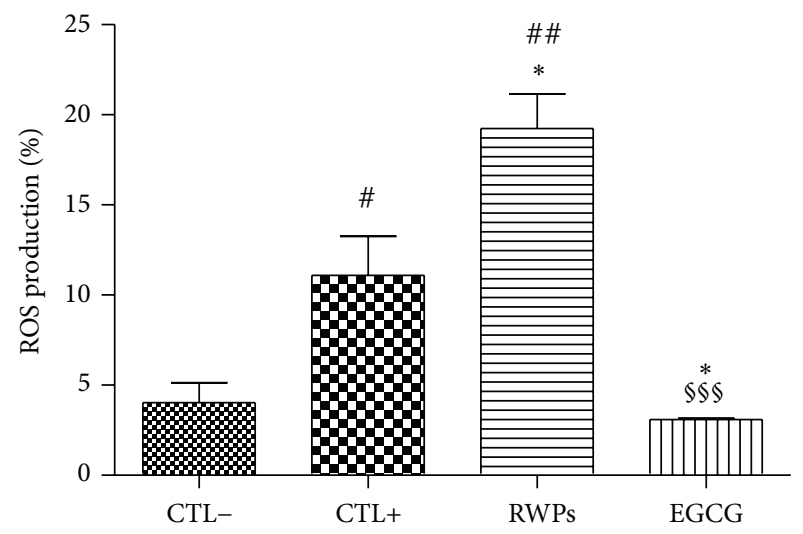

(d)

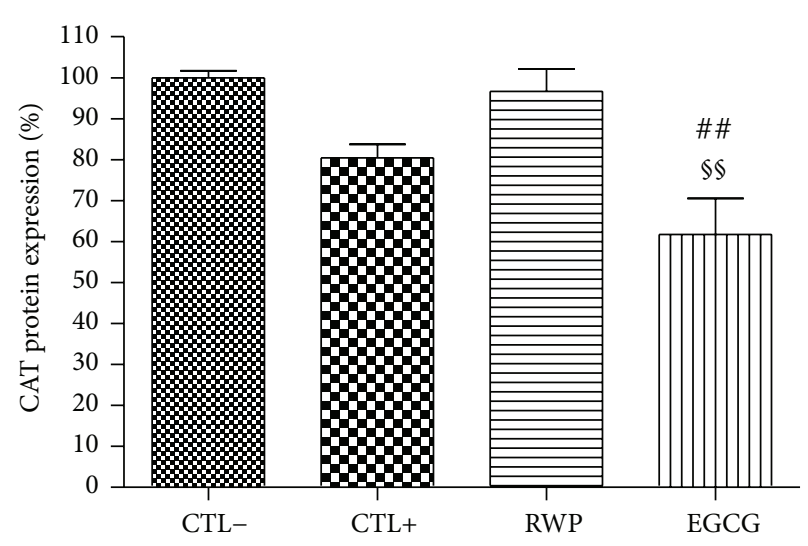

(f)

FIGURE 3: Effects of the antioxidants RWPs and EGCG on cell viability ( $a, b)$, caspase 8 activity/apoptosis (c), ROS production (d), MnSOD expression (e), and CAT expression ( $\mathrm{f}$ ) during $\mathrm{H}_{2} \mathrm{O}_{2}$-induced oxidative stress. Values are given as the mean \pm SEM for three different experiments. $n=6$; ${ }^{*} P<0.05$ and ${ }^{* *} P<0.01$ compared to the unstressed control cells (CTL-); ${ }^{\#} P<0.05$, ${ }^{\# \#} P<0.01$ compared to the stressed control cells (CTL+); ${ }^{\S} P<0.05,{ }^{\$ \S} \mathrm{P}<0.01$, and ${ }^{\$ \$ \S} \mathrm{P}<0.001$ compared to the stressed cells treated with RWPs.

\section{Discussion}

In the present study, we sought to accurately determine the antioxidant properties of two specific natural compounds,
RWPs and EGCG. In doing so, we have demonstrated that antioxidant properties depend not only on the nature of the compound itself, but also on the type of oxidative stress induced. These data show, for the first time, that using one 


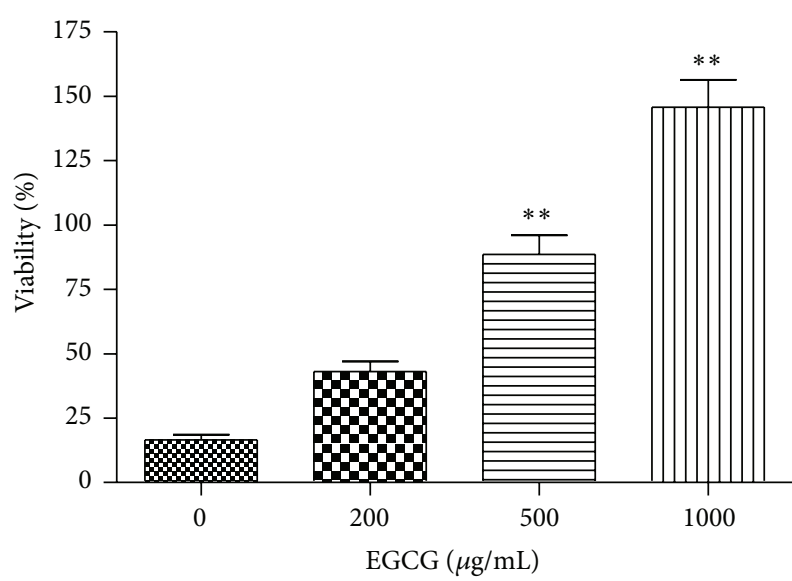

(a)

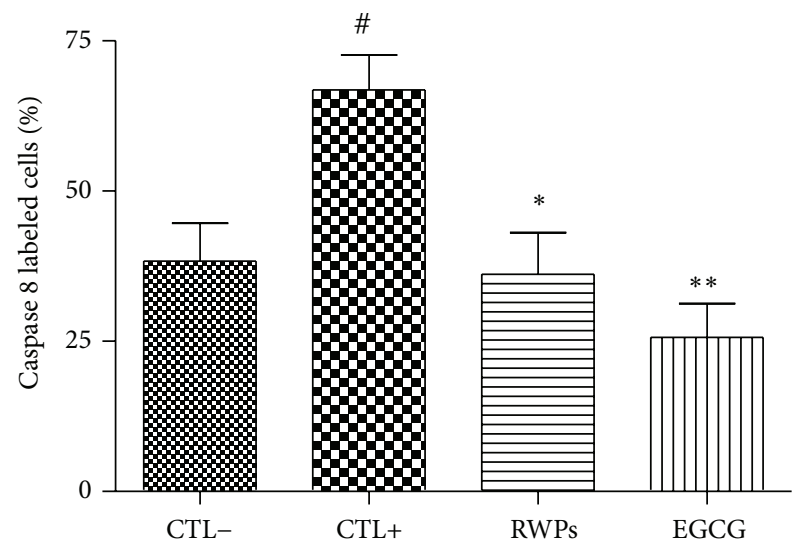

(c)

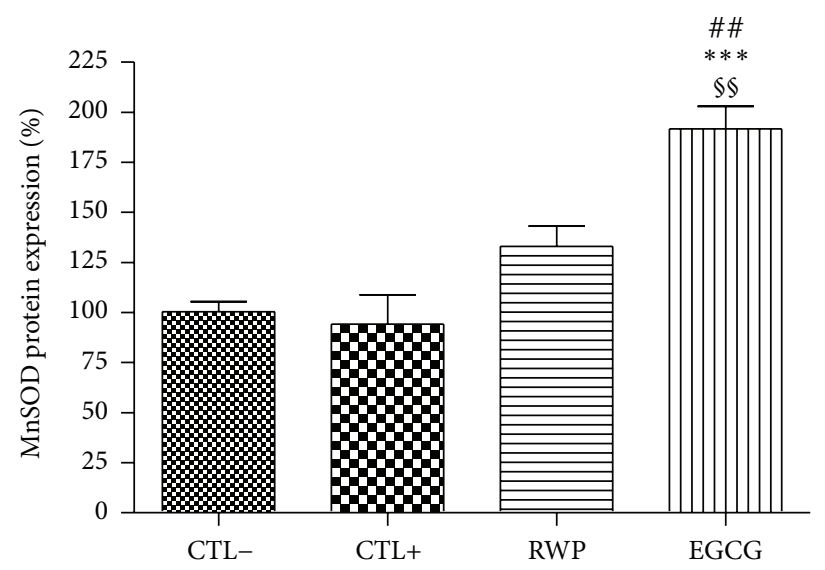

(e)

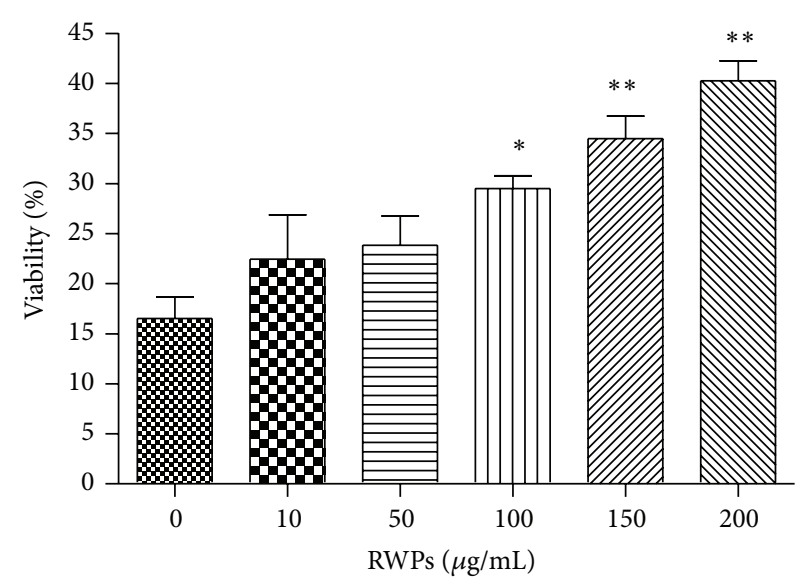

(b)

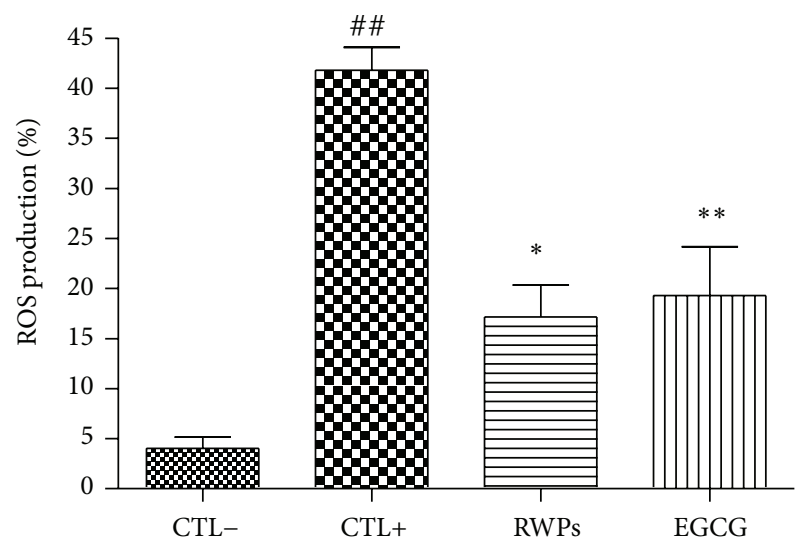

(d)

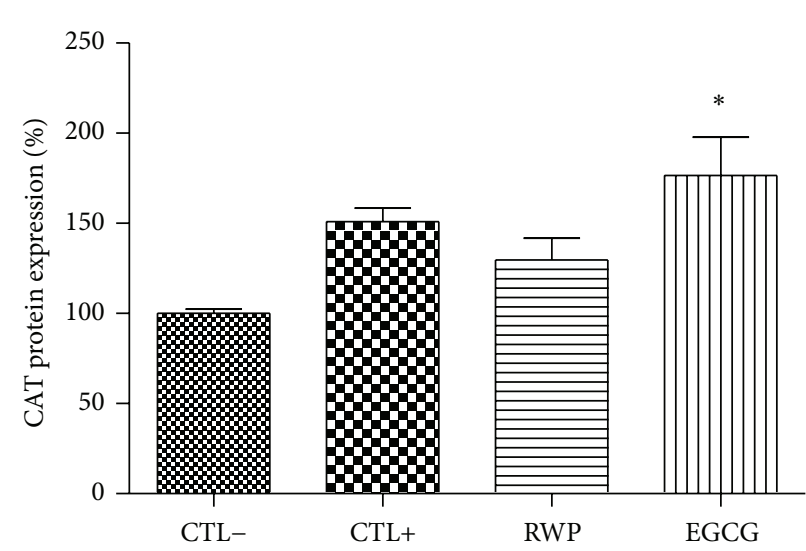

(f)

FIGURE 4: Effects of the antioxidants RWPs and EGCG on cell viability (a, b), caspase 8 activity/apoptosis (c), ROS production (d), MnSOD expression (e), and CAT expression ( $\mathrm{f}$ ) during HX/XO-induced oxidative stress. Values are given as the mean \pm SEM for three different experiments. $n=6 ;{ }^{*} P<0.05,{ }^{* *} P<0.01$, and ${ }^{* * *} P<0.001$ compared to the unstressed control cells $(\mathrm{CTL}-) ;{ }^{\#} P<0.05,{ }^{\# *} P<0.01$ compared to the stressed control cells $(\mathrm{CTL}+) ;{ }^{\S \S} \mathrm{P}<0.01$ compared to the stressed cells treated with RWPs.

model of oxidative stress is not sufficient to make meaningful conclusions concerning the action of an antioxidant, particularly in regard to disease-related oxidative stress.

Complex mechanisms related to glucose autoxidation and hyperinsulinism, which increase ROS production, have been identified in diabetes [5]. Further, the increased level of ROS has been associated with beta cell apoptosis, which, in time, induces insulin dependence $[34,35]$. In order to decrease beta cell oxidative stress, nutraceutical approaches have been developed focusing on the screening of plant extract [36-38]. 


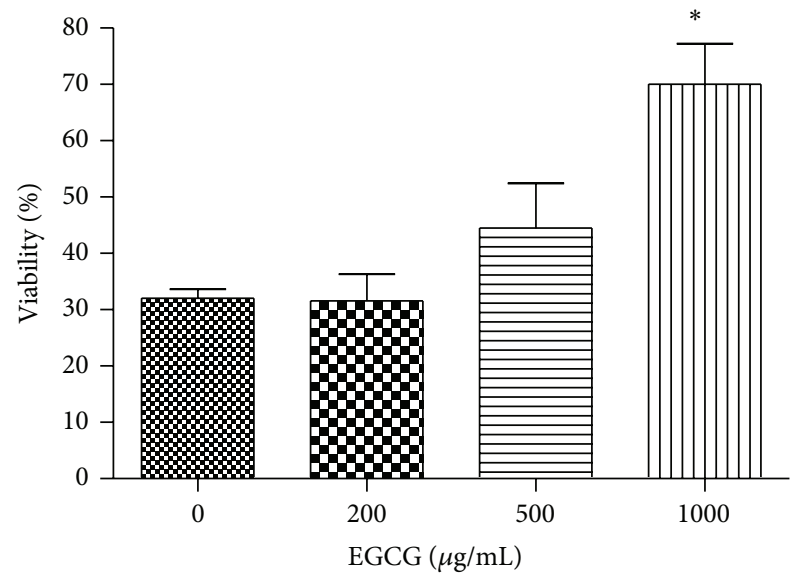

(a)

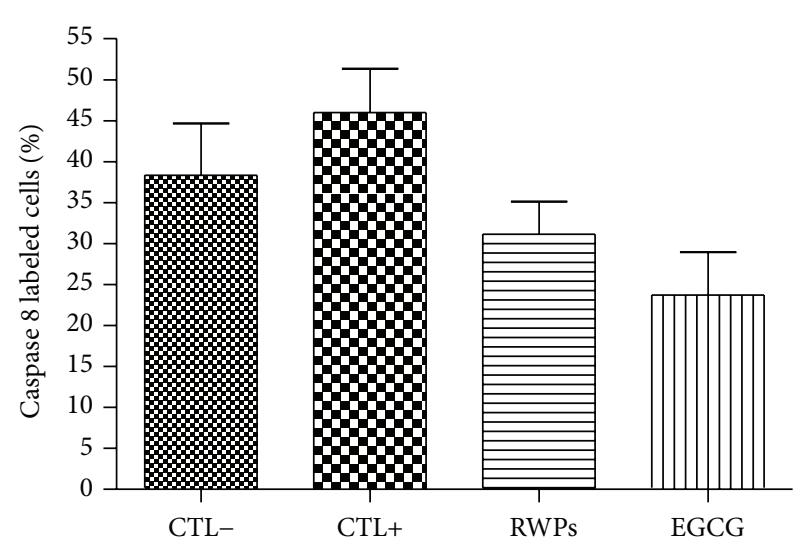

(c)

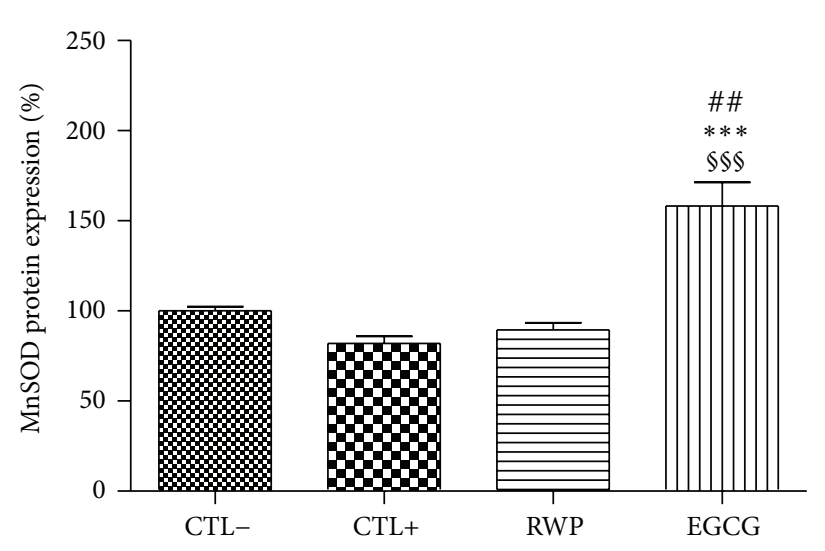

(e)

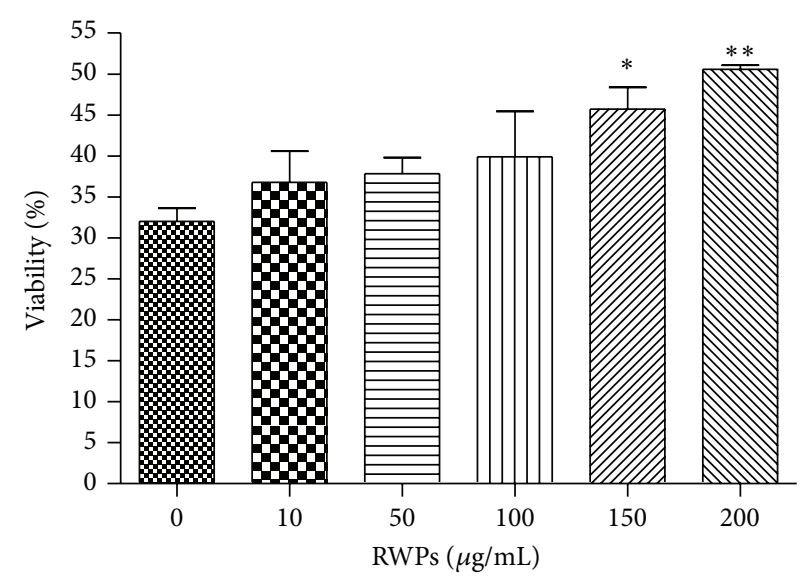

(b)

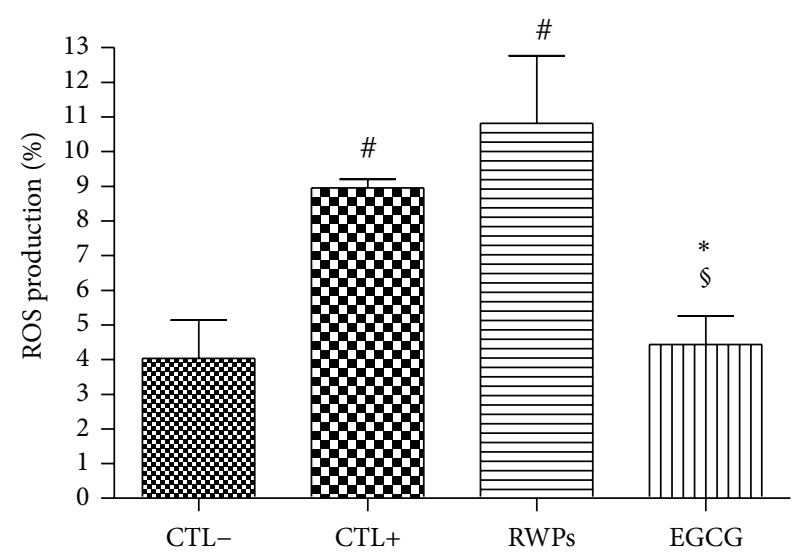

(d)

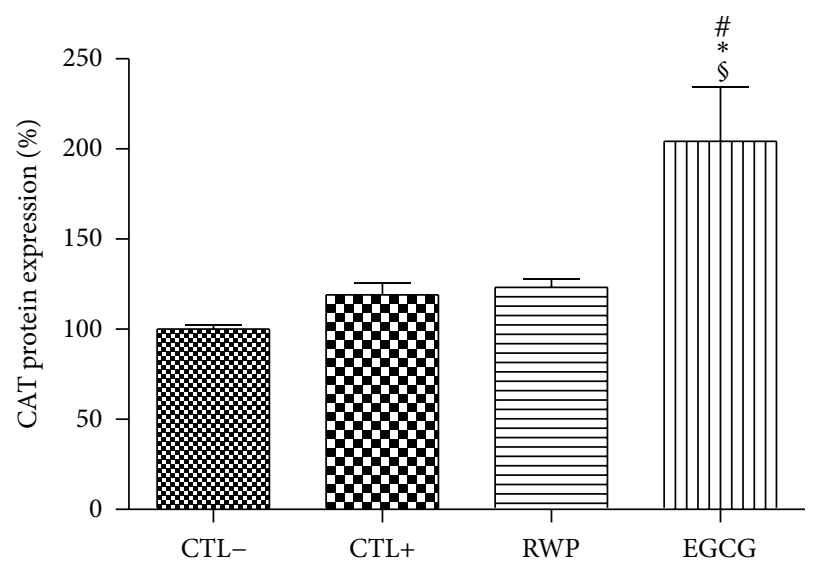

(f)

FIGURE 5: Effects of the antioxidants RWPs and EGCG on cell viability (a, b), caspase 8 activity/apoptosis (c), ROS production (d), MnSOD expression (e), and CAT expression (f) during STZ-induced oxidative stress. Values are given as the mean \pm SEM for three different experiments. $n=6$; ${ }^{*} P<0.05,{ }^{* *} P<0.01$, and ${ }^{* * *} P<0.001$ compared to the unstressed control cells $(\mathrm{CTL}-)$; ${ }^{\#} P<0.05$, ${ }^{\# \#} P<0.01$ compared to the stressed control cells (CTL+); ${ }^{\S} \mathrm{P}<0.05,{ }^{\$ \varsigma S} \mathrm{P}<0.001$ compared to the stressed cells treated with RWPs.

For the initial screening, the efficiency of the bioactive compounds in the plant is currently validated in vitro using a single type of oxidative stress [27, 39-41]. Here, in order to provide a comprehensive overview of ROS generated in diabetes, we have utilized three models of oxidative stress to screen our bioactive compounds.

Not surprisingly, the level of cell death induced by each type of oxidative stress studied was similar. However, the level 
of ROS produced in the cells was found to be higher in the $\mathrm{HX} / \mathrm{XO}$ model compared to the others. In fact, our data show that there is no correlation between ROS production and the level of cell death, indicating that cell viability alone is not an accurate marker of the oxidative stress response in a cell or tissue. This is in contrast to several previous studies that have linked oxidative stress to cell viability $[3,26,28]$. Notably, the conclusions in these studies were all based on single models of oxidative stress. We chose to measure ROS production in parallel with other markers of the cellular stress response, such as changes in SOD and CAT expression as well as the caspase 8 activity in the cells, in order to evaluate the full effect of the oxidant. According to these results, the cellular defence mechanisms, characterised by SOD and CAT expression, were more activated by the $\mathrm{HX} / \mathrm{XO}$-induced stress, which is correlated to the higher level of ROS. Thus, we suggest that antioxidant enzymes likely play a crucial role in cell protection following the introduction of oxidative stress, particularly because the cell viability was comparable to the other conditions as previously described $[21,40]$. This phenomenon in the HX/XO experiments could also be explained by the type of radical generated. In fact, the stress induced by $\mathrm{H}_{2} \mathrm{O}_{2}$ and STZ was more complex (ROS generation via NADPH oxidase activation and/or NO synthase) compared to that generated by HX/XO (direct ROS provider), which may result in the latter inducing the cell's response to stress earlier or more efficiently. Additional work is necessary to further elucidate the differing effects caused by the various free radicals.

Using the three stress models outlined here in conjunction with parallel investigations of ROS generation and cellular defence mechanisms to screen bioactive compounds also provided more detailed information on the cellular stress response. For example, in these experiments, EGCG appeared to be a better antioxidant for the three types of different stresses induced, with a decrease in ROS production and an activation of MnSOD and CAT expression, whereas RWPs were shown to be efficient only on the strongest stress $(\mathrm{HX} / \mathrm{XO})$ and even then only had a limited influence on antioxidant enzyme expression. Thus, the use of multiple types of free radical stress indicates that EGCG is likely the most efficient scavenger [26] and pharmacological treatment [37] investigated in this study. This is corroborated by a previous study that demonstrated the neuroprotective effects of EGCG involving inhibition of the Fenton reaction and upregulation of several antioxidant enzymes, such as superoxide dismutase and catalase, resulting in the attenuation of oxidative stress [42]. In contrast, the antioxidant properties of RWPs seem to be solely related to scavenging during severe changes in oxidative stress. Moreover, our study suggests that RWPs may be both antioxidant and prooxidant because we observed an increase of ROS production when RPWs were added during $\mathrm{H}_{2} \mathrm{O}_{2}$ oxidative stress. It is well known [43] that polyphenols extract could autoxidize and produce more hydrogen peroxide. In our study, we have demonstrated in this condition that RWPs have no impact on SOD or CAT protein expression but other protective mechanisms could be activated like the stimulation of CAT and SOD activity or a direct action glutathione or thioredoxin. Notably, while we sought to use the same concentration of compound (pure or extract) for both RWPs and EGCG, the composition of these compounds made this impractical. Using HPLC [29], it appears that the raw RWP extract also contains several flavonoids (epicatechin, catechin, and gallic acid) but is found at concentrations that are 100 times less than that of the pure EGCG used in this study. This composition could explain the relatively low efficiency of RWPs shown here. In contrast, the pure EGCG extract was able to activate antioxidant pathways through several mechanisms, which could be due to the high concentration of the flavonoids present.

Regardless of the composition of the compounds, if only one oxidative stress model had been used or only one ROS or cell death assay had been performed, then it is unlikely that the complex nature of these antioxidants would have been uncovered. Therefore, we believe that the sole use of one model or one assay to validate the efficiency of bioactive compounds in the current literature $[30,32]$ greatly limits the scope and conclusions of these studies. Further, a more precise determination of cell death, ideally using additional apoptosis signalling pathways, like additional caspase activation, antiapoptotic Bcl-xL, and proapoptotic Bax expression $[27,37]$, as well as further analysis of oxidation-related enzymes could also be utilized to expand our current analysis. Additional work is necessary to determine the full functionality of our multitype oxidative stress model in testing the antioxidant properties of other compounds.

\section{Conclusion}

Here, we have demonstrated that the level of ROS generated by different oxidative stresses was variable and a drug screening using a single kind of stress can introduce bias in the estimation of the antioxidant properties of a compound. Therefore, a combination of several stresses and several cellular and molecular approaches would provide a more accurate experimental text to determine if the compound is an efficient antioxidant. This in vitro model also more accurately mimics the in vivo biological situation, which will help avoid unnecessary spending of money and time when transitioning a bioactive antioxidant treatment from the context of cell culture to clinical validation. Taken together, this study provides a much needed method for the comprehensive assessment of antioxidants for the treatment of oxidative stressrelated diseases.

\section{Abbreviations}

$\begin{array}{ll}\text { 7'AAD: } & \text { 7-Aminoactinomycin D } \\ \text { ABAM: } & \text { Antibiotic-antimycotic } \\ \text { CAT: } & \text { Catalase } \\ \text { DCF: } & \text { Dichlorofluorescein } \\ \text { DCFH-DA: } & 2^{\prime}, 7^{\prime} \text {-Dichlorofluorescein-diacetate } \\ \text { DNA: } & \text { Deoxyribonucleic acid } \\ \text { EDTA: } & \text { Ethylenediaminetetraacetic acid } \\ \text { EGCG: } & \text { Epigallocatechin gallate } \\ \text { FAM: } & \text { Carboxyfluorescein } \\ \text { FBS: } & \text { Fetal bovine serum } \\ \text { HX/XO: } & \text { Hypoxanthine/xanthine oxidase }\end{array}$


iNOS: Inducible NO synthase

MnSOD: Manganese superoxide dismutase

NO: $\quad$ Nitric oxide

PBS: $\quad$ Phosphate-buffered saline

RINm5F: Rat pancreatic cell line

ROS: $\quad$ Reactive oxygen species

RWPs: Red wine polyphenols

SEM: $\quad$ Standard error of the mean

SOD: $\quad$ Superoxide dismutase

STZ: Streptozotocin

TCA: Tricarboxylic citric acid.

\section{Conflict of Interests}

The authors declare that there is no conflict of interests regarding the publication of this paper.

\section{Acknowledgments}

The authors would like to express their gratitude to "Vaincre le Diabète" and ASDIA (Assistance Service DIAbete) for partially funding this project.

\section{References}

[1] K. Grankvist, S. L. Marklund, and I. B. Taljedal, "CuZnsuperoxide dismutase, $\mathrm{Mn}$-superoxide dismutase, catalase and glutathione peroxidase in pancreatic islets and other tissues in the mouse," Biochemical Journal, vol. 199, no. 2, pp. 393-398, 1981.

[2] H. Sies, "Role of reactive oxygen species in biological processes," Klinische Wochenschrift, vol. 69, no. 21-23, pp. 965-968, 1991.

[3] S. R. Sampson, E. Bucris, M. Horovitz-Fried et al., "Insulin increases $\mathrm{H}_{2} \mathrm{O}_{2}$-induced pancreatic beta cell death," Apoptosis, vol. 15, no. 10, pp. 1165-1176, 2010.

[4] A. Y. Andreyev, Y. E. Kushnareva, and A. A. Starkov, "Mitochondrial metabolism of reactive oxygen species," Biochemistry, vol. 70, no. 2, pp. 200-214, 2005.

[5] S. Lenzen, "The mechanisms of alloxan- and streptozotocininduced diabetes," Diabetologia, vol. 51, no. 2, pp. 216-226, 2008.

[6] A. Favier, "Oxidative stress in human diseases," Annales Pharmaceutiques Francaises, vol. 64, no. 6, pp. 390-396, 2006.

[7] K. Fisher-Wellman and R. J. Bloomer, "Macronutrient specific postprandial oxidative stress: relevance to the development of insulin resistance," Current Diabetes Reviews, vol. 5, no. 4, pp. 228-238, 2009.

[8] M. D. Brand, A. L. Orr, I. V. Perevoshchikova, and C. L. Quinlan, "The role of mitochondrial function and cellular bioenergetics in ageing and disease," British Journal of Dermatology, vol. 169, no. 2, pp. 1-8, 2013.

[9] M. Latha, L. Pari, S. Sitasawad, and R. Bhonde, "Scoparia dulcis, a traditional antidiabetic plant, protects against streptozotocin induced oxidative stress and apoptosis in vitro and in vivo," Journal of Biochemical and Molecular Toxicology, vol. 18, no. 5, pp. 261-272, 2004.

[10] C. Gökkuşu, Ş. Palanduz, E. Ademoğlu, and S. Tamer, “Oxidant and antioxidant systems in niddm patients: influence of vitamin E supplementation," Endocrine Research, vol. 27, no. 3, pp. 377386, 2001.
[11] H. P. Ammon, R. Hägele, N. Youssif, R. Eujen, and N. ElAmri, "A possible role of intracellular and membrane thiols of rat pancreatic islets in calcium uptake and insulin release," Endocrinology, vol. 112, no. 2, pp. 720-726, 1983.

[12] S. Lenzen, J. Drinkgern, and M. Tiedge, "Low antioxidant enzyme gene expression in pancreatic islets compared with various other mouse tissues," Free Radical Biology and Medicine, vol. 20, no. 3, pp. 463-466, 1996.

[13] R. Hägerkvist, S. Sandler, D. Mokhtari, and N. Welsh, "Amelioration of diabetes by imatinib mesylate (Gleevec): role of betacell NF-kappaB activation and anti-apoptotic preconditioning," The FASEB Journal, vol. 21, no. 2, pp. 618-628, 2007.

[14] S. M. Virtanen and A. Aro, "Dietary factors in the aetiology of diabetes," Annals of Medicine, vol. 26, no. 6, pp. 469-478, 1994.

[15] R. A. Kinloch, J. M. Treherne, L. M. Furness, and I. Hajimohamadreza, "The pharmacology of apoptosis," Trends in Pharmacological Sciences, vol. 20, no. 1, pp. 35-42, 1999.

[16] C. Rice-Evans, "Plant polyphenols: free radical scavengers or chain-breaking antioxidants?" Biochemical Society symposium, vol. 61, pp. 103-116, 1995.

[17] A. Sarkar and A. Bhaduri, "Black tea is a powerful chemopreventor of reactive oxygen and nitrogen species: comparison with its individual catechin constituents and green tea," Biochemical and Biophysical Research Communications, vol. 284, no. 1, pp. 173-178, 2001.

[18] Y.-H. Kao, H.-H. Chang, M.-J. Lee, and C.-L. Chen, "Tea, obesity, and diabetes," Molecular Nutrition and Food Research, vol. 50, no. 2, pp. 188-210, 2006.

[19] R. Rodrigo, A. Miranda, and L. Vergara, "Modulation of endogenous antioxidant system by wine polyphenols in human disease," Clinica Chimica Acta, vol. 412, no. 5-6, pp. 410-424, 2011.

[20] C. Sandoval-Acuña, J. Ferreira, and H. Speisky, "Polyphenols and mitochondria: an update on their increasingly emerging ROS-scavenging independent actions," Archives of Biochemistry and Biophysics, vol. 559, pp. 75-90, 2014.

[21] S. Lortz and M. Tiedge, "Sequential inactivation of reactive oxygen species by combined overexpression of SOD isoforms and catalase in insulin-producing cells," Free Radical Biology and Medicine, vol. 34, no. 6, pp. 683-688, 2003.

[22] C. Moriscot, M. J. Richard, M. C. Favrot, and P. Y. Benhamou, "Protection of insulin-secreting INS-1 cells against oxidative stress through adenoviral-mediated glutathione peroxidase overexpression," Diabetes and Metabolism, vol. 29, no. 2 I, pp. 145-151, 2003.

[23] R. Zhang, Q. Zhang, J. Niu et al., "Screening of microRNAs associated with Alzheimer's disease using oxidative stress cell model and different strains of senescence accelerated mice," Journal of the Neurological Sciences, vol. 338, no. 1-2, pp. 57-64, 2014.

[24] A. Ceriello and E. Motz, "Is oxidative stress the pathogenic mechanism underlying insulin resistance, diabetes, and cardiovascular disease? The common soil hypothesis revisited," Arteriosclerosis, Thrombosis, and Vascular Biology, vol. 24, no. 5, pp. 816-823, 2004.

[25] K.-B. Kwon, J.-H. Kim, Y.-R. Lee et al., "Amomum xanthoides extract prevents cytokine-induced cell death of RINm5F cells through the inhibition of nitric oxide formation," Life Sciences, vol. 73, no. 2, pp. 181-191, 2003.

[26] K. M. Ramkumar, A. S. Lee, K. Krishnamurthi et al., "Gymnema montanum $\mathrm{H}$. Protects against alloxan-induced oxidative stress 
and apoptosis in pancreatic $\beta$-cells," Cellular Physiology and Biochemistry, vol. 24, no. 5-6, pp. 429-440, 2009.

[27] S. A. Kalekar, R. P. Munshi, and U. M. Thatte, "Do plants mediate their anti-diabetic effects through anti-oxidant and anti-apoptotic actions? An in vitro assay of 3 Indian medicinal plants," BMC Complementary and Alternative Medicine, vol. 13, article 257, 2013.

[28] K. Dembele, K. H. Nguyen, T. A. Hernandez, and B. L. G. Nyomba, "Effects of ethanol on pancreatic beta-cell death: interaction with glucose and fatty acids," Cell Biology and Toxicology, vol. 25, no. 2, pp. 141-152, 2009.

[29] C. Auger, B. Caporiccio, N. Landrault et al., "Red wine phenolic compounds reduce plasma lipids and apolipoprotein B and prevent early aortic atherosclerosis in hypercholesterolemic golden Syrian hamsters (Mesocricetus auratus)," Journal of Nutrition, vol. 132, no. 6, pp. 1207-1213, 2002.

[30] A. Mira, A. Tanaka, Y. Tateyama, R. Kondo, and K. Shimizu, "Comparative biological study of roots, stems, leaves, and seeds of Angelica shikokiana Makino," Journal of Ethnopharmacology, vol. 148, no. 3, pp. 980-987, 2013.

[31] C. H. Kim and Y.-M. Yoo, "Melatonin induces apoptotic cell death via p53 in LNCaP cells," Korean Journal of Physiology and Pharmacology, vol. 14, no. 6, pp. 365-369, 2010.

[32] L. Liu and S.-Y. Wang, "Protective effects of paeoniflorin against a $325-35$-induced oxidative stress in PC12 cells," Zhongguo Zhong Yao Za Zhi, vol. 38, no. 9, pp. 1318-1322, 2013.

[33] M. M. Bradford, "A rapid and sensitive method for the quantitation of microgram quantities of protein utilizing the principle of protein-dye binding," Analytical Biochemistry, vol. 72, no. 1-2, pp. 248-254, 1976.

[34] V. Z. Lankin, M. V. Ivanova, G. G. Konovalova, A. K. Tikhaze, A. I. Kaminnyi, and V. V. Kukharchuk, "Effect of $\beta$-hydroxy$\beta$-methylglutaryl coenzyme a reductase inhibitors and antioxidant vitamins on free radical lipid oxidation in rat liver," Bulletin of Experimental Biology and Medicine, vol. 143, no. 4, pp. 414417, 2007.

[35] P. P. Singh, F. Mahadi, A. Roy, and P. Sharma, "Reactive oxygen species, reactive nitrogen species and antioxidants in etiopathogenesis of diabetes mellitus type-2," Indian Journal of Clinical Biochemistry, vol. 24, pp. 324-342, 2009.

[36] U. Karunakaran and K.-G. Park, "A systematic review of oxidative stress and safety of antioxidants in diabetes: focus on islets and their defense," Diabetes and Metabolism Journal, vol. 37, no. 2, pp. 106-112, 2013.

[37] S.-H. Lee, S.-M. Kang, S.-C. Ko, M.-C. Kang, and Y.-J. Jeon, "Octaphlorethol A, a novel phenolic compound isolated from Ishige foliacea, protects against streptozotocin-induced pancreatic beta cell damage by reducing oxidative stress and apoptosis," Food and Chemical Toxicology, vol. 59, pp. 643-649, 2013.

[38] M. Á. Martín, S. Ramos, I. Cordero-Herrero, L. Bravo, and L. Goya, "Cocoa phenolic extract protects pancreatic beta cells against oxidative stress," Nutrients, vol. 5, no. 8, pp. 2955-2968, 2013.

[39] L. A. Flores-López, M. Díaz-Flores, R. García-Macedo et al., "High glucose induces mitochondrial p53 phosphorylation by p38 MAPK in pancreatic RINm5F cells," Molecular Biology Reports, vol. 40, no. 8, pp. 4947-4958, 2013.

[40] V. Nadithe, D. Mishra, and Y. H. Bae, "Poly(ethylene glycol) cross-linked hemoglobin with antioxidant enzymes protects pancreatic islets from hypoxic and free radical stress and extends islet functionality, Biotechnology and Bioengineering, vol. 109, no. 9, pp. 2392-2401, 2012.
[41] F. M. M. Paula, S. M. Ferreira, A. C. Boschero, and K. L. A. Souza, "Modulation of the peroxiredoxin system by cytokines in insulin-producing RINm5F cells: down-regulation of PRDX6 increases susceptibility of beta cells to oxidative stress," Molecular and Cellular Endocrinology, vol. 374, no. 1-2, pp. 56-64, 2013.

[42] O. Weinreb, T. Amit, S. Mandel, and M. B. H. Youdim, "Neuroprotective molecular mechanisms of (-)-epigallocatechin-3gallate: a reflective outcome of its antioxidant, iron chelating and neuritogenic properties," Genes and Nutrition, vol. 4, no. 4, pp. 283-296, 2009.

[43] J. Zhu, W. J. M. van de Ven, T. Verbiest et al., "Polyphenols can inhibit furin in vitro as A result of the reactivity of their autooxidation products to proteins," Current Medicinal Chemistry, vol. 20 , no. 6 , pp. 840-850, 2013. 


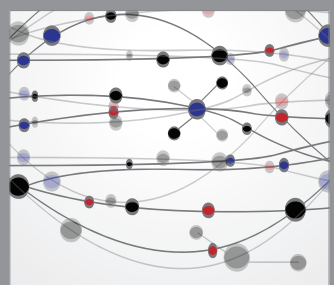

The Scientific World Journal
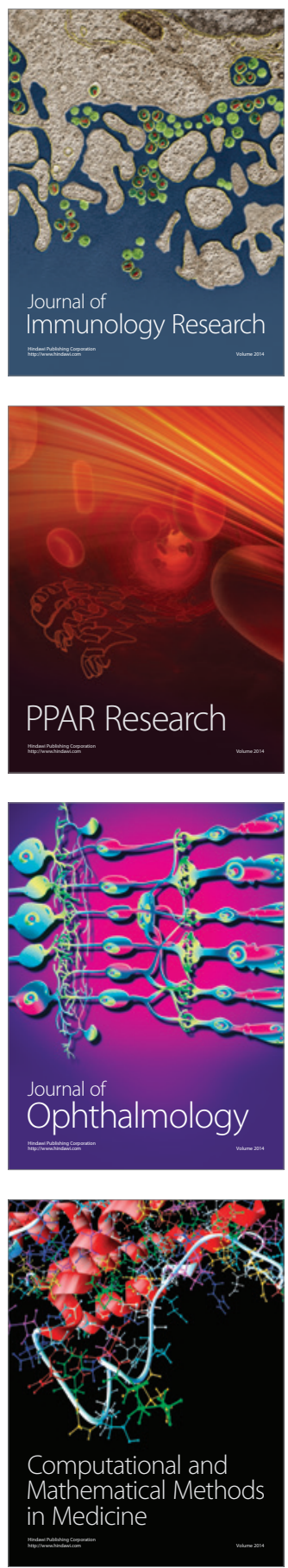

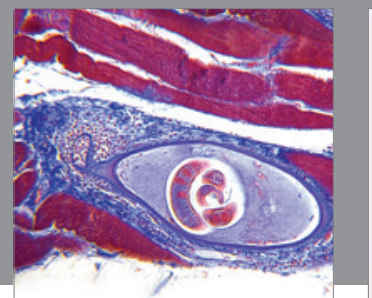

Gastroenterology

Research and Practice
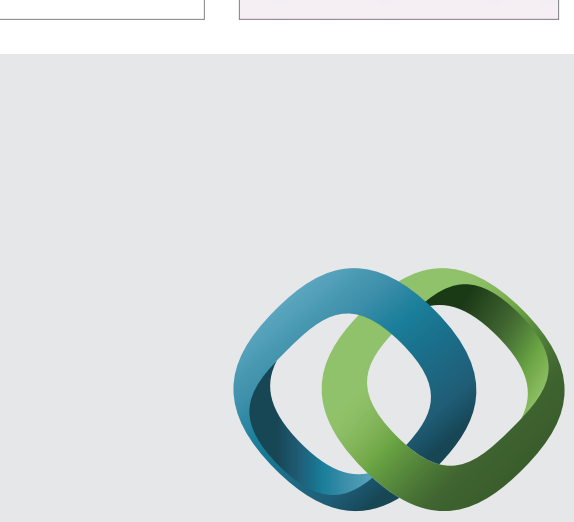

\section{Hindawi}

Submit your manuscripts at

http://www.hindawi.com
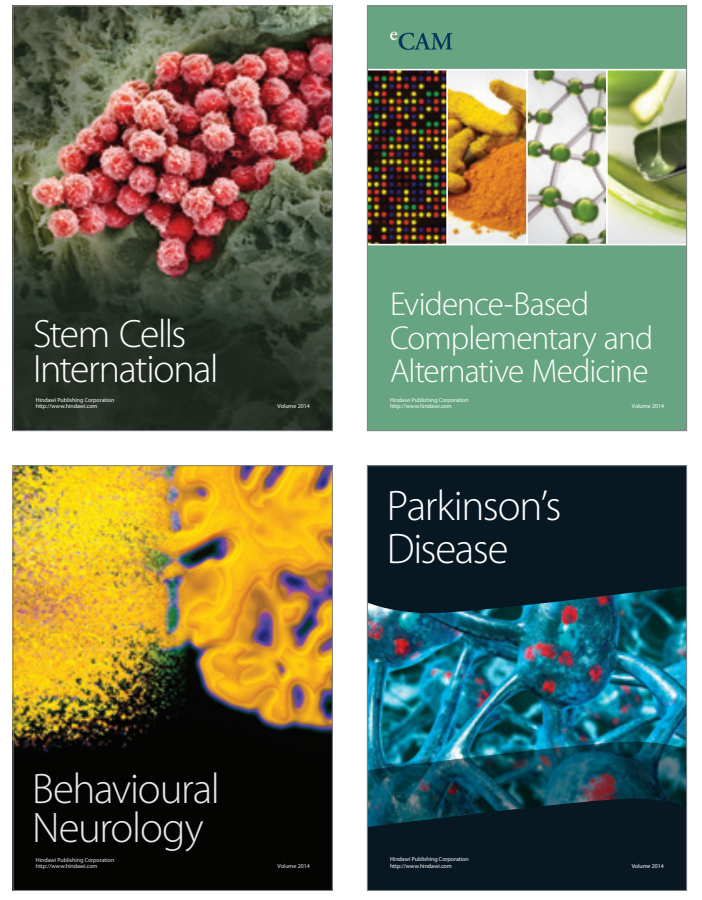
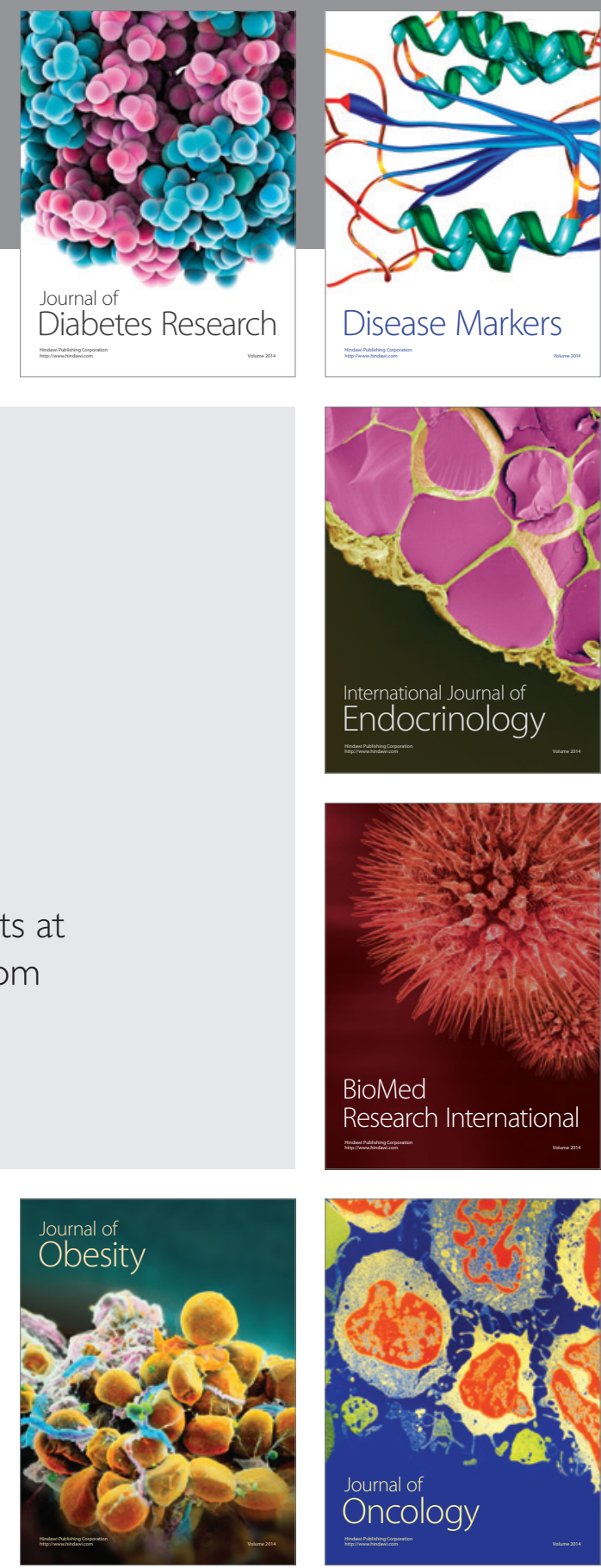

Disease Markers
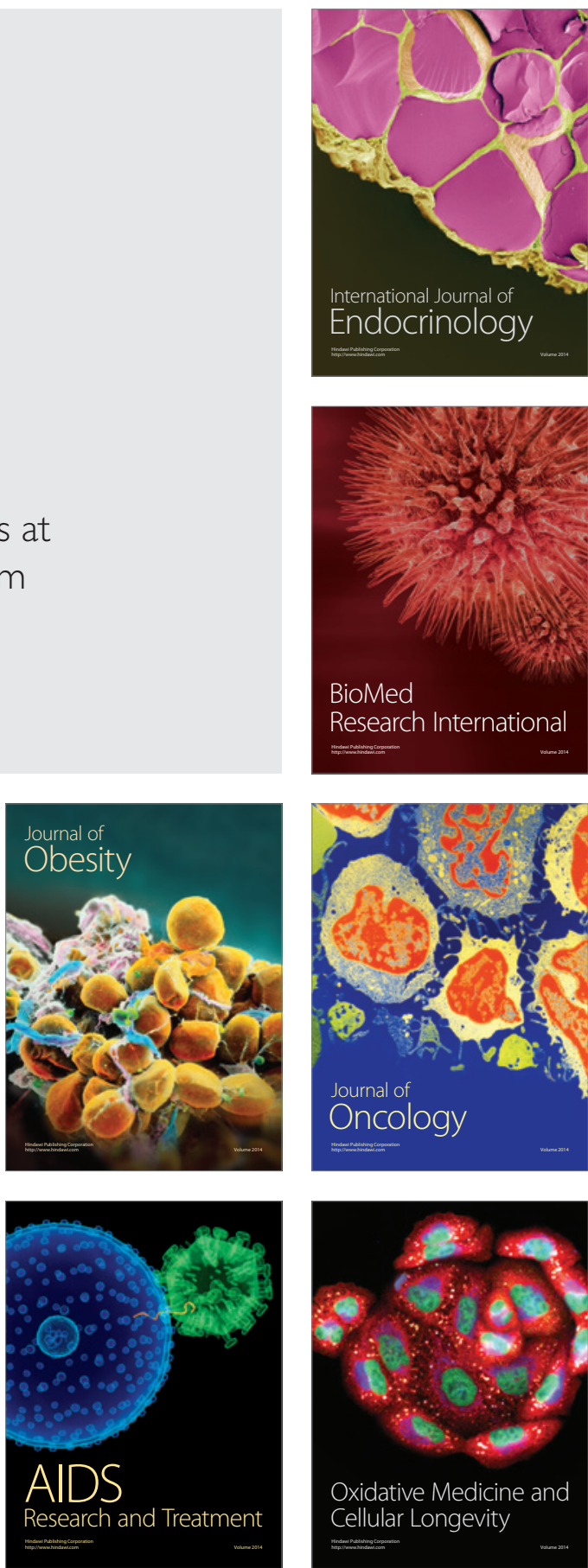